\title{
UNITED STATES AND THE INVASION OF TEXAS, $1810-1814$
}

\section{INTRODUCTION}

7 HE chronicle of United States relations with the Mexican Republic has been one marked by professed sympathy, misunderstanding, and undisguised hostility. All three descriptions may be applied to the earliest official and extralegal contacts between the peoples of these neighboring countries. Such turmoil has understandably léd to diverse interpretations by not a few historians in the United States, and probably the most confused period in this chronicle was that of 1810 to 1814 when the accredited United States Agent William Shaler became involved in a government sponsored project aimed at influencing the struggle for Mexican independence. ${ }^{1}$

The intent of this work is to study the events that culminated in the invasion of Imperial Spain's domain of Nueva España during August, 1812. By a concentration on certain details confidentially penned by Shaler to his superior, Secretary of State James Monroe, two aspects previously misinterpreted stand out: a) The military force of North American volunteers that left Natchitoches, Louisiana, to join Mexican revolutionaries was not simply a filibustering expedition, but represented the United States Government's first foreign policy towards Mexico. It was an integrated part of a premeditated scheme which anticipated an independent Mexico under the guidance and protection of the United States. b) Shaler's participation in this invasion reflected that of an official, though secret, United States representative following a broadly based series of instructions from his superiors in Washington.

The object of the United States is to exclude all European influence from this hemisphere. -Thomas Jefferson, 1808

Since its independence the attitude of the United States towards Spain's colonies in the New World reflected the fear of encroachment

1 Roy F. Nichols, Advance Agents of American Destiny (Philadelphia: University of Pennsylvania Press, 1956), p. 83. 
by Great Britain and France. Such a dread was natural. The United States had recently won its freedom from the former nation and wished to maintain it, while brisk commercial activity with Spanish America would serve to establish relations and promote alliances that might benefit both continents of the Western Hemisphere. Napoleon's European aggressiveness and subsequent conquest of Spain also threatened to destroy the beginning of any such inter-hemisphere cooperation, albeit the threat was remote. During their terms as president, Jefferson (1801-1808) and Madison (1809-1816) committed their country to a somewhat vacillating position regarding Spanish America, and both sought to gain territory in Spanish Florida and the Mexican province of Texas. Fear of British or Napoleonic reprisal, however, temporarily served to contain these schemes. It must be remembered that in 1797 England seized Trinidad, and in 1806 British troops invaded the Rio de le Plata region, occupying the Viceroyalty of Buenos Aires and the Governorship of Montevideo. ${ }^{2}$

In spite of the United States Government's profound political, social, and geographic ignorance of New Spain and South America, the nation's commercial sector had been aware of the area's import-export potentials since the American Revolution, when a clandestine trade had commenced. ${ }^{3}$ One contemporary estimate of the amount of trade to Nueva España from the rest of the world for the first decade of the nineteenth century totaled twenty millions of dollars. Much of this amount found its way to the traditional contraband centers of New Orleans, Charleston, Baltimore, and Boston. ${ }^{4}$ A more recent estimate reveals that between 1796 and 1806 North American commercial relations with Nueva España and South America increased from three to twelve per cent of the total United States export trade. Finally, an eyewitness on the United States-Texas border in 1812 tallied the arrival of one shipment bound for New Orleans at $\$ 100,000 .^{5}$ It is apparent that with such large sums involved, United States merchants exerted considerable influence on the development of their nation's Latin Ameri-

2 John Niles, $A$ View of South America and Mexico (New York: H. Huntington, Jr, 1826), p. 116. Cf. Arthur Whitaker, The United States and the Independence of Latin America (New York: W. W. Norton, 1964), pp. 24-37.

${ }^{3}$ Niles, op. cit.; Whitaker, op. cit., p. 2.

${ }^{4}$ Niles, op. cit., p. 104 . Niles claimed that during that $W$ ar of 1812 , steel sold in Mexico fetched as high a price as $\$ 260$ per hundred pounds. Whitaker, op. cit., p. 12. New England merchants played such a prominent part in the contraband trade with Mexico that the natives referred to all North Americans as "Bostoneses."

5 National Archives (hereafter referred to as NA), State Department, Special Agents, vol. II, Shaler to Monroe, 18 August 1812. 
can policy, especially when prominent commercial entrepreneurs held high government posts. ${ }^{6}$

North American interest in New Spain was also founded on long range economic and political considerations. The region's population during the struggle for independence was estimated at 8,902,995 persons, which represented a vast untapped market for North American products and a source of such raw materials as iron, copper, mercury, and sugar. ${ }^{7}$ These extended plans, however, were also vulnerable to threats from British commercial interests which, in the first decade of the nineteenth century, were more proficient than their former colonists, and already enjoyed favorable relations with Mexico because of Britain's alliance with Spain against Napoleon. One contemporary noted that viceroyalty officials in Nueva España were "indulgent to an excessive and undignified degree" with English officials and merchants. Current to this report was an account that achieved some credibility because of an apparent debate in the Cortes of Cádiz, and involved the surrendering of Southern Cuba to the British. ${ }^{8}$

When one considers that, parallel to United States interest in Latin America there ran throughout much of the country an expansionist feeling that found expression in demanding war with England, the inter-relationship of these aspirations during Madison's first term obviously became very complicated and interdependent. A successful penetration of the Mexican and South American markets would require the careful timing of any opening of hostilities. In effect the United States was attempting to monopolize the entire Western Hemisphere by commercial penetration of Spanish America, and at the same time capture Canada while Britain struggled in the morass of Napoleonic wars. This was the crux of President Madison's Third Annual Message to Congress on 5 November 1811 which, besides embodying a carefully worded but undisguised challenge to England, contained a prophetic statement on Spanish America:

In contemplating the scenes which distinguish this momentous epoch, and estimating their claims to our attention, it is impossible to overlook those developing themselves among the great communities which

${ }^{6}$ Whitaker, op. cit., p. 56. Madison's first Secretary of State, Robert Smith, was instrumental in the appointment of special agents to Latin America. This is understandable when one learns that he and his brother were prominent Baltimore merchants engaged in Spanish American trade.

'Niles, op. cit., p. 110. The population of the United States at this time was not much larger, possibly 10,000,000.

${ }^{8}$ NA, Shaler to Smith, 9 August $1810 ; 12$ August 1810, copy to the President. 
occupy the southern portion of our own hemisphere and extend into our neighborhood. An enlarged philantropy [sic] and an enlightened forecast concur in imposing on the national councils an obligation to take a deep interest in their destinies, to cherish reciprocal sentiments of good will, to regard the progress of events, and not to be unprepared for whatever order of things may be ultimately established. ${ }^{9}$

Before these statements were made, however, Madison had prepared for the eventual outcome of the "order of things" by dispatching special agents to key Spanish American localities. Vera Cruz was assigned to the Connecticut Yankee and sometime Latin American expert, William Shaler.

\section{II}

The volunteer expedition from the most insignificant beginning is growing into an irresistible torrent, that will Sweep the crazy remains of Spanish Government from the Internal Provinces, and open Mexico to the political influence of the U.S. and to the talents and enterprize of our citizens.

-Shaler to Monroe, 5 October 1812

Having frequented several Spanish American ports as a seaman-merchant, learned the Spanish tongue and translated Juan Ignacio Molina's Geograpbical, Natural and Civil History of Chile William Shaler possessed credentials for the position of Special Agent as good as could have been found among United States citizens in 1810. Shaler, according to the authority of Roy Nichols, had fomented rebellion among the Criollo families of Valparaiso, Chile, and San Blas, Nueva España in 1802, leaving Spanish copies of his country's Declaration of Independence and Constitution before hasty departures. ${ }^{10}$ His background must have been known to at least Secretary of State Smith who was probably professionally acquainted with Shaler through his merchant connections. It might be stated, then, that Shaler was chosen, as were other agents, for his previous revolutionary and commercial activities among Spanish Americans as well as for his disdain for Imperial Spanish authority and his audacity. This point was apparently overlooked by Professor Nichols in his accounts of Shaler's activities on the Mexican-United States border since Nichols leaves the definite impression

\footnotetext{
${ }^{9}$ James D. Richardson, ed., Messages and Papers of the Presidents, II (New York: Bureau of National Literature, Inc., 1897), 479.

${ }^{10}$ Roy F. Nichols, "William Shaler, New England Apostle of Rational Liberty," New England Quarterly, IX (March, 1936), 73-76. Caught by the Spanish for stealing sea otters, Shaler defiantly destroyed their fort at San Diego. The tale of this escapade was still popular during the 1830 's.
} 
that Shaler acted much on his own and outside the scope of his instructions from Washington. It is hard to conceive that men of Madison's (and subsequently Monroe's) stature would appoint a representative noted for his revolutionary activities to a land seething in rebellion for the purpose of assuring "Latin Americans of the good will of the government of the United States" while forbidding him "to interfere in local affairs or to encourage any armament against Spain. ..." Again, according to Nichols, Shaler was to "make it plain to whatever authorities he met, that the United States would not permit any Spanish territory to come under the sway of any other power. If danger of encroachment arose, the United States would extend help and protection." 11

Arthur Whitaker, on the other hand, noted that Shaler's first duty was to foster his country's commercial interests and, in view of the possibility that Nueva España might succeed in gaining its independence,

to diffuse the impression that the United States cherish the sincerest good will towards the People of Spanish America as neighbors and it would coincide with the sentiments and policy of the United States to promote most friendly relations and most liberal intercourse between inhabitants of this hemisphere.

Whitaker states, however, that Shaler was "guilty of serious indiscretions" while engaged in promoting the invasion of Mexico. ${ }^{12}$

It was obvious that Shaler's appointment as special agent would require what is known currently as a cover and therefore he carried credentials as "consul for Vera Cruz" and "commercial agent to both Havana and Vera Cruz." 13 His real mission, however, must be inferred from his background and the subsequent events on the Mexican frontier of which he gave a full report to Secretary of State Monroe and President Madison for nearly a year without being contradicted. It is possible, though, to reconstruct his actual duties from his letters to his superiors during his stay at Natchitoches. Apparently Shaler was to cooperate with any Mexican revolutionary agents, sent to him or that he encountered, in the organization of a revolutionary provisional government; supply these Mexican agents with whatever funds he deemed necessary for the successful completion of their missions, and with the aid of a printing press circulate propaganda aimed at the overthrow of the Viceroyalty of New Spain. In addition, Smith and his

11 lbid., pp. 76-77.

12 Whitaker, op. cit., pp. 65-66.

${ }^{13}$ NA, Shaler to Smith, 16 June 1810; Nichols, op. cit., p. 76; Whitaker, op. cit., p. 63. 
replacement, Monroe, must have agreed to Shaler's efforts to open communications and commerce with the interior provinces of Nueva España while hindering the clandestine activities of agents representing any European powers.

Because Vera Cruz was in royalist hands and closed to foreigners, Shaler was forced to abandon his trip to that city where his exposure would certainly have led to the extreme embarrassment of his government. Then, after a year's stay at Havana in an unsuccessful attempt to gather intelligence regarding the rebellion in Tierra Firme, Shaler took ship for New Orleans on 11 December $1811 .{ }^{14}$

While awaiting orders in the city, Shaler learned what news he could of the Mexican insurgents and dutifully reported to his superior that the rebels were recovering from the royalist blow that cost them their leader, Padre Hidalgo. He also observed on 30 March 1812 that the rebel "General Rayón at the head of a numerous army was posted at twenty-five leagues from the Capital; that his artillery consisting of 400 pieces of brass cannon is commanded by an American of the name of General Smith." In the final paragraph of this report Shaler remarked that the Mexican "Colonel Bernard, of whose arrival here I have the honor to inform you .... has, agreeably to the wish of the Governor (of Louisiana), been lodged with me." ${ }^{15}$

The aforementioned "Colonel Bernard" was actually José Bernardo Gutiérrez de Lara, a criollo merchant from Revilla who was appointed colonel in the Revolutionary Army by Hidalgo in 1811. When a volunteer was requested to conduct a mission to Washington for the purpose of seeking arms and volunteers, Gutiérrez offered his services. Given official instructions and credentials, the Colonel departed on 17 April 1811 and arrived in Washington the following winter. But because of a skirmish with the royalist forces before crossing the border, he lost all " papers and dispatches which proved my commission in a' positive manner." ${ }^{16}$

Spending nights at the homes of many influential North Americans during his journey enabled Gutiérrez to gain a consensus of their feelings for the Mexican insurrection. Writing in his diary of his meet-

${ }^{14} \mathrm{NA}$, ten letters from Shaler to Smith dated from 1810 through 1811. Nichols, op. cit., p. 84. NA, Shaler to Monroe, 13 January 1812.

15 NA, Shaler to Monroe, 9 March 1812; Shaler to Monroe, 30 Mar. 1812.

16 "Diary of José Bernardo Gutiérrez de Lara," American Historical Review, XXXIV (October, 1928), 56-57; Harris G. Warren, The Sword was Their Passport (Baton Rouge: University Press, 1943), p. 5. 
ing with several state militia generals and governors, the Colonel remarked he had "found them all attentive to our just cause. They made me many offers and aided me to reach their government." With not a little exaggeration, Gutic̀rrez also penned that "the rest of the people principally in Kentucky and Tennessee . . . did not even want me to proceed, wishing me to remain there, and saying that they would make up a considerable army of volunteers, with which, under my command, we would invade the provinces of Mexico and sweep before us all the oppressors of our liberty." Even if his statements were inflated, it was obvious the Mexican cause was well received over the path of his journey. ${ }^{17}$

Upon his arrival in the Capital City, Gutiérrez secured an appointment with Secretary of War Eustis who asked his opinion regarding an Ámerican occupation of Nacogdoches, Nueva España (on the west bank of the Sabine River). Secretary Eustis related that the United States could have easily fielded an army all the way to the Rio Grande "under the pretext," admitted the Secretary, "that they were going to take possession of the lands which France had sold them, and that being there the army could help the creoles." Gutiérrez politely refused this generous offer, but did accept living expenses and travelling funds for his return trip. When Eustis again pressed the United States' willingness to invest the Mexican province of Texas, Gutiérrez countered with a proposal "to leave a certain portion of land as a neutral (tract), to separate the two nations" and eliminate future boundary discords. Bernardo's stubbornness apparently annoyed Eustis who promptly terminated the meeting for that day. At the next session, however, the Secretary bluntly announced his government's intention to take possession of the aforementioned territory. Gutiérrez claimed to have replied that he "could not note upon these things, nor could they treat of them with me; that only the Supreme Government could decide them; but even after this they wish my opinion. Maria Santisima, help me and rescue me from these men! "18

Subsequent to these dialogues, the colonel was received by the President and then ushered into Secretary of State Monroe's office for a private conference. There Monroe, he claimed, explained to him that

it was expedient for me to go back to my country to fetch the documents necessary to undertake the purchase of arms, and to report the friendly disposition of this country to favor the Republic of Mexico. He told me also, that so great was the extent of which he was inter-

17 Gutiérrez Diary, op. cit., p. 59.

18 Ibid., pp. 71-73; Niles, op. cit., p. 148. 
esting himself in this cause, that as soon as I presented myself and made my reports this government immediately wrote to its Ambassadors in France, England, and Denmark in order to charge them to bend all their energies toward showing those powers how expedient it is for them that all the colonies of Spain become independent. ${ }^{19}$

Finally, and apparently with high drama, Gutiérrez claimed Monroe emphatically stated that if the United States were to declare war on Great Britain the North American Government would "immediately place an army of 50,000 men in our country (Mexico) to aid our independence and make common cause with us." Gutiérrez dryly thanked Monroe on behalf of his nation and wryly requested him "that what he said to me verbally they should do me the favor to give me in writing." Monroe replied that he would consult the highest authority and submit a reply. ${ }^{20}$

Taking his leave of Washington during January 1812, the Colonel sailed from Philadelphia for New Orleans and upon his arrival was introduced, sometime in March, by Governor Claiborne of Louisiana to William Shaler. Shaler, Bernardo noted in his diary, "made me move to his lodgings; and we agreed to set out for (the Louisiana border post of) Natchitoches together." Shaler apparently never informed Gutiérrez of his position as a special agent because the Colonel later suspected him to be a spy for his government. One Mexican historian has even asserted that Shaler's main purpose, since the time of his appointment in 1810 , had been to get " such connection with the Mexican Republic as would enable him to manipulate it in the interest of the U. S." This historian also described Shaler as a "shrewd politician, an excellent linguist, an unscrupulously devoted patriot, attractive, diplomatic, and a cripple." 21

Shaler, however, was impressed with the Mexican Colonel, especially since he carried a letter of introduction from the Chief Clerk of the State Department. Bernardo's refusal to communicate with agents of various foreign powers unless they were presented by Governor Claiborne or Shaler furthered the latter's esteem. Two months of close relationship from sharing the same rooms did nothing to alter this impression. Shaler reported to Monroe that Bernardo's views ap-

${ }^{19}$ Gutiérrez Diary, op. cit., p. 73. Cf. Hubert H. Bancroft, History of the Nortb Mexican States and Texas, II (San Francisco: The History Company, 1889), 20.

${ }^{20}$ Gutiérrez Diary, op. cit., pp. 73-75. Bernardo was also given an opportunity to raise funds by being introduced to widows of means. This apparently shocked the married Colonel.

${ }^{21}$ Lorenzo de la Garza, Dos Hermanos Heroes as quoted in Gutiérrez Diary, loc. cit., pp. $289 \mathrm{f}$. 
peared to be " prudent and honorable, he communicates everything to me and declares that he will listen to no proposals whatever without my approbation." 22

On 7 April 1812 Shaler, to " conform to the wishes of the President," paid for his own and Gutiérrez's passage to Natchitoches. Agreeing with his instructions wholeheartedly, Shaler noted that if Bernardo had been left to his own resources in New Orleans, "he must from necessity have fallen into the hands of persons who might have engaged him in views very different from those of the President." Shaler also believed he had won Gutiérrez to the cause of constitutional republicanism by portraying the despotic governmental systems of the countries represented by foreign agents who had tried to contact him. Shaler then concluded to Monroe that Gutiérrez would not "engage in any plan'whatever without my approbation." ${ }^{23}$

While the special agent observed and reported his every movement in Natchitoches, Gutiérrez put his energy behind recruiting a military force that later resulted in a preponderance of North American names on the roster. Advertising locally as well as in distant Natchez, the Criollo Colonel offered forty dollars monthly wages plus one league of land to each of those that put their mark on the muster rolls. Not neglecting the opposite border, Bernardo distributed broadsides throughout Northeastern Texas to prepare his path once an expedition forded the Sabine. He expected to be joined by hundreds of criollos once he was on Mexican soil. To heighten the excitement, several mysterious persons from Nashville and Natchez frequented Shaler's and Gutiérrez' lodgings as well as French agents offering unbelievable sums for the promotion of the revolution. ${ }^{24}$

Much of the summer of 1812 was passed in such fashion, and events apparently accelerated at a faster pace than Shaler was able to monitor. As early as 12 June he expressed his belief that possibly three expeditions were forming for an aggregate total of more than 1,000 North Americans. By the nature of his appointment, however, Shaler was forced to remain in the shadows while Bernardo negotiated for the accouterments of war. He was therefore not privy to every detail

22 NA, Shaler to Monroe, 30 March 1812; Shaler to Monroe, 7 May.

23 Ibid., Shaler to Monroe, 2 May 1812.

${ }^{24}$ Walter M'Caleb, "The First Period of the Gutiérrez-Magee Expedition," Quarterly of the Texas State Historical Association, IV (January, 1901), 218-19.

NA, Shaler to Monroe, 7 May 1812; Shaler to Monroe, 12 June with enclosure. A French agent called Paillet had offered Bernardo $\$ 100,000$ in cash and 400 trained troops for the invasion. 
associated with outfitting the expedition. In the same letter as mentioned above, Shaler attempted to explain this dilemma to his superior, and after apologizing for the scanty intelligence remarked, "I am suspected to be a public agent, and my opinions are well known and all such information is carefully kept from me." Shaler also sought to protect his identity from Gutiérrez. ${ }^{25}$

Bernardo, meanwhile, had succeeded in convincing the local United States Army post commander of his cause's value. Lieutenant Augustus W. Magee had been placed in command at Natchitoches to suppress the numerous bandits that operated with impunity between that place and Nacogdoches. The offer of a colonelcy and leadership of the invasion, however, was sufficient cause for Magee to post his resignation and promptly proceed to devise strategy with Bernardo. ${ }^{26}$

Whether Shaler participated in the military aspects of the invasion is uncertain, but he did formulate several documents relating to the organization of a provisional government, and in addition guided Bernardo in his report to the last remaining insurgent Mexican force commanded by Rayón. Copies of many of these documents were forwarded to Monroe who was thus thoroughly acquainted with their details and with Shaler's intentions. ${ }^{27}$

On 12 July while the expedition was still being formed, Shaler wrote Monroe, expressing his satisfaction that the President had approved of his actions thus far since "I have to act entirely according to my own conceptions of what may be his wishes." Probably with regret, Shaler noted that he was regarded as the "cunning director" of the forthcoming invasion and expressed puzzlement over Bernardo's most recent actions in that the latter was apparently withholding news from him. He also lamented the control that others of his countrymen had "gained upon the mind of Bernardo (so) as to destroy all his confidence in me." Nevertheless, he assured Monroe that he had not altered his confluct toward Bernardo "in the business and I intend . . . to suffer myself to be deceived so far as to advance him a small sum of money if he requests it." 28

While the aforementioned events were transpiring, the United States openly courted a war with England in pursuance of its expansionist

$25 \mathrm{lbid}$.

${ }^{26}$ M'Caleb, op. cit.; Gutiérrez Diary, op. cit., p. 291.

27 NA, Shaler to Monroe, 12 June 1812; Shaler to Monroe, 12 July with enclosures; Bernardo to Rayón, 12 June, in Spanish.

28 lbid., Shaler to Monroe, 12 July. 
policies. Before hostilities commenced Shaler became preoccupied with the impact a war with Britain would have on the proposed expedition and the United States position vis-a-vis Nueva España. Evaluating the implications that might result from these circumstances, Shaler apprehensively outlined to Monroe what might occur on his frontier:

... If Great Britain determines a war with the United States, She will also determine to transport the government of Cádiz (i. e., the rump Spanish Government trapped by Napoleon) to Mexico. The evacuation of the peninsula of Spain seems to be a necessary consequence of war with us, when she will have a disposable force more than equal to such an enterprize in the present state of things, and should She succeed in that undertaking we should be greatly exposed in our weakest part. I therefore conclude that in the event of war, it will be considered a matter of indispensible necessity to open a communication with the Republicans of the interior of New Spain; to arm them, to organize them, and to put them in a state to resist such an invasion if possible.

Lamenting the scarcity of details regarding the terrain except for "what is contained in Humboldt," Shaler considered a force of 5,000 men sufficient to open contacts with the Republican armies. "I suppose," he continued, "that a large proportion of this force might consist of (North American) volunteers: as the service would be popular, there would be no other difficulty than in the selection of proper officers." If, however, the force was unable to effect a successful revolution against the Spanish in Mexico, then Shaler believed "we should at least be able to offer an assistance to the fugitives to organize and discipline them, and help defending the passage of the Rio Grande to secure Louisiana from invasion in this quarter." ${ }^{20}$

The above account differs remarkably from that proposed by Professor Nichols who, it appears, not only misquoted the italicized phrases of Shaler's dispatch, but also removed them from their contextual relationship in an apparent effort to bulwark his thesis that Shaler was operating outside his instructions at Natchitoches. The Nichols version appears as follows:

Filibustering was the interest of the moment, and Shaler was beset. The United States was in a precarious international position: war with Great Britain was approaching, and the Government could not afford to offend Spain no matter how interested in liberty her citizens might be. . . . Torn between sympathy and duty, Shaler made concessions to the former at the expense of the latter. In spite of neutrality, perhaps it was 'a matter of indispensable necessity to open a

${ }^{29} \mathrm{NA}$, Shaler to Monroe, 7 May 1812. Italics are mine. 
communication with the Republicans (in Mexico) ... to arm them, to organize them, and to put them in a state to resist such an invasion.' The best way out of the dilemma was for the War Department to send down an army to guard the frontier, prevent filibustering, and get in touch with Mexico or at least 'offer an Assylum (sic) to the fugitives, organize and discipline them.' ${ }^{30}$

A simple comparison suffices to show that Professor Nichols' rendition leaves something to be desired. It is clear Shaler meant that the United States should fear an invasion and not Mexico, that is, a Spanish invasion of Louisiana in its capacity as an ally of Britain. The War Department was urged to send a force to the frontier, not to prevent filibustering, but to cross the border and open communications with the Republicans. Then if this United States recruited force failed to defeat forces brought from Spain by Britain (see above), the survivors could be gathered at the frontier to stem any Spanish tide that might engulf the exposed flank that was Louisiana. While it may appear that much of the above represents somewhat of a digression from the mainstream of this work, the conclusion reached pertinently serves to reinforce the contentions implied in the introduction, that is, the coloring of the questioned documents by Professor Nichols for the apparent furtherance of his own theme leads one to wonder about the validity of that theme.

\section{III}

If therefore you can obtain possession of San Antonio and make a stand there the situation of your Mexican friends will be eligible and prospects fair.

\section{-Shaler to Commander of the Invasion}

Force, 20 December 1812

By early August 1812, the invasion force had assembled on the North American bank of the Sabine and consisted of hunters, trappers, and adventurers from Kentucky, Louisiana, Tennessee, and Mississippi. It was, nevertheless, truly an international band with French, Italian, Spanish from Louisiana, and Mexicans from Texas in its ranks. Numbering from approximately 130 to 500 effectives armed with rifles and shotguns, the force penetrated Spanish territory at several points during 8 August. $^{31}$ Unable to observe their departure because of a fever, Shaler later reconstructed the exciting event for his superiors. He

${ }^{30}$ Nichols, op. cit., pp. 88-89.

31 NA, Shaler to Monroe, 18 August 1812. Cf. Paul Wellman, Glory, God and Gold (Garden City: Doubleday \& Co., Inc., 1954), pp. 208-11. Wellman's account makes no mention of Shaler. Cf. also Gutiérrez Diary, op. cit., p. 59. 
assured them there had " never been within the territory of the United States the least appearance of armament, or military preparation, the volunteers went out either singly, or in small bands, usually armed as hunters, and what few Supplies have been procured here have been furnished in the common way of trade." ${ }^{32}$

A few historians have considered this invasion to be nothing more than a temporary incursion of Nueva España, labeling it a raid or a filibuster, which betrays a misconception of the expedition's purpose. ${ }^{33}$ Although many of the North Americans joined the force for reasons of land, loot, and adventure, the guiding purpose of its commanders and many in the ranks was the seizure of Texas for the proclaimed Republic of Mexico. Then, if this enterprise proved successful, vague plans had been promoted to continue through the interior provinces in ordeŕ to effect a link with insurgent forces operating there. ${ }^{34}$

Encountering sporadic and half-hearted Spanish resistance, the force rapidly advanced to Nacogdoches and captured it within the week. While the first excitement of victory circulated through the surrounding regions, the army busied itself with recruiting, and its ranks swelled as Mexicans, alerted by Bernardo's broadsides, and additional North Americans converged on the once sleepy Spanish outpost. Shaler observed the passage of his fellow countrymen through Natchitoches and estimated that the volunteers would shortly exceed $500 \mathrm{men}$. $\mathrm{He}$ also notified Monroe of his intent to follow the army "as soon as I hear of the volunteers being in quiet possession of San Antonio," the capital of Spanish Texas. By 25 August, Shaler calculated the army's North American strength at 200 additional men, and on 5 September the special agent reported a total of 450 North Americans and 330 Mexicans in the force. ${ }^{35}$

Subsequent to the capture of Nacogdoches, the arrival there of reinforcements, and reports from captured Spanish troops of the excellent discipline displayed by Bernardo's army, Governor Claiborne issued a proclamation condemning the campaign. In what must have been sardonic humor, Shaler remarked to Washington his regret that the proclamation had not been issued a month sooner, "when the enterprize might have been quashed. . . ." It may be assumed, however, that the governor was aware of the expedition and waited to observe its initial

32 NA, Shaler to Monroe, 7 August 1813.

33 Warren, op. cit., p. 28; Nichols, op. cit., p 91. Cf. Bancroft, op. cit. p. 19.

34 NA, Shaler to Monroe, 25 August 1812; Shaler to Monroe, 12 June 1813; Shaler to Monroe, 20 June 1813, enclosure dated 25 May; Shaler to Monroe, 14 July.

35 lbid., 18 August, 25 August, 5 September, 1812. 
success before officially protesting. It must be remembered that, because the force's majority consisted of North Americans, and because the United States was formally at peace with Spain, some type of protest was necessary. ${ }^{36}$

In an effort to further this subterfuge, Secretary Monroe had early prepared a scheme which called for an accredited United States representative to visit Spanish authorities in Mexico. A month before the invasion was launched, Monroe instructed Dr. John Robinson, a man thoroughly versed in Mexican ways, to proceed to the Internal Provinces and express to any Spanish authorities that he encountered Washington's displeasure over border intrusions from the north. "It is for their mutual interest," Monroe counseled, "that this banditti (sic) should be suppressed." ${ }^{37}$

Gutiérrez, meanwhile, had overcome his initial apprehension over the invasion's prospects and sent Shaler a copy of his first proclamation which the latter managed to have published in the Alexandria, Louisiana Herald. The document contained high praise for the North American volunteers: "It breathes that spirit of patriotism and liberty, which has always characterized its author; and guarantees to the RePUBLICAN Heroes, who have volunteered in the cause of the enslaved and oppressed Mexicans, that honorable reward worthy of such generous souls." Bernardo exuberantly promised future volunteers Mexican citizenship, free lands, and the right to "work and dispose of any mines of gold, silver, or whatever, the right of taming and disposing of wild horses and mules" in addition to any surplus of confiscated property. Such generosity circulated with the intensity of a brush fire fanned by hurricane winds, and within a month Shaler reported that "the business of Volunteering for New Spain has become a perfect mania; I hear of parties proceeding thither from all quarters, and they are constantly passing thro' this village from Natches." Shaler estimated, that 600 North Americans, "equal even to the entire conquest of the Provinces of the Incas," had joined Bernardo's forces. The strength of the North American volunteers continued to predominate and Shaler revised his totals in November to 800 North Americans and 200 Mexicans. ${ }^{38}$

38 Ibid., 25 August 1812.

37 NA, Department of State, Mexico Filibustering Expedition Against the Government of Spain 1811-1816; Monroe to Robinson, 1 July 1812. For an accurate account of Robinson's adventures, see: Isaac Cox, "Monroe and the Early Mexican Revolutionary Agents," Annual Report of the American Historical Association, I (Washington: A. H. A., 1913), 199-215.

${ }_{38}$ NA, Shaler to Monroe, 1 October 1812; Shaler to Monroe, 10 November; Bancroft, op. cit., p. 21. 
One occurrence, however, served to mar the smooth progression of the invasion. Shaler had learned of the Colonel's speech to the inhabitants of Bayou Aux Pierres, a village within the borders of the United States. It was rumored that during the speech Gutiérrez threatened the male population with imprisonment unless they agreed to serve his cause. Uncertain as to the validity of his source, Shaler tactfully reproached Bernardo and reminded him that he was drawing his "very existence from these States." A few days later, Shaler learned that the Colonel had published a proclamation which was being promulgated in the village by one Marcelle (sic) de Soto. At the head of a file of United States soldiers, Shaler descended upon the town only to learn that the proclamation had never been printed. Upon returning to Natchitoches, Shaler found a letter from Bernardo in which the latter vehemently denied the utterance of any such threat. With this, the matter was prudently ignored by both Shaler and Gutiérrez. ${ }^{39}$

The treatment this episode was accorded by Professor Nichols, however, is curious. Subsequent to an explanation, wherein he asserts Shaler was instructed by Monroe to stay "free from any connections with the invaders," Nichols claims Shaler "took Monroe's instructions to heart," and

when a new complication arose, he acted vigorously. As soon as he heard that Bernardo was attempting to recruit in a village in the neutral ground, he took a detachment of soldiers to prevent-only to discover that the people of Bayou aux Pierres were not heeding the Mexican's pretensions.

Professor Nichols has assumed Bernardo's guilt when it was very probable that no such event had occurred. ${ }^{40}$

As winter approached, Shaler and much of the Southwest United States was electrified as word was received of continuing victories by the invading force; both Trinidad and La Bahía had been invested by November. In the lull following these achievements, Gutiérrez presented Shaler with an apparently unsolicited scheme involving Mexico's union with the United States. Two conditions were necessary before Gutiérrez would consent: that Shaler remain with Bernardo "to prevent me from erring \& Second that a Sufficient military force to secure what we have conquered from the ennemy (sic) be furnished with all possible brevity." Shaler dutifully passed a copy of the proposal to

\footnotetext{
${ }^{39}$ NA, Shaler to Monroe, 10 October 1812; Shaler to Monroe, 10 November with enclosures from Gutiérrez, undated and in Spanish.

${ }^{40}$ Nichols, op. cit., p. 92.
} 
Washington without comment. On 29 November Gutiérrez again pursued a similar plan and asked Shaler if he "would continue to furnish us with some relief and would join us." "You and I," he continued, "would treat this Subject with the greatest prudence, every thing would be as we desire it, not a drop of blood woud be spilt and this country would be happy." ${ }^{41}$

Word soon reached Gutiérrez and his field commander Magee that royalist forces were massing for an attack on La Bahía. Shaler was forced to abandon any consideration that he might give to a unification scheme in order to prevent the two insurgent leaders from ordering a retreat or surrendering. A very despondent Magee wrote Shaler on 25 November, "My hopes of effecting a Revolution in this country, with the means I now hold, are entirely blasted. . .." Unaware that Magee was suffering from a fatal illness and consequently despairing, Shaler replied exhorting him to victory. "I expect that any counsel in my power to give would be like 'mustard after dinner," "Shaler modestly claimed. With more honesty he continued, "No person has been more jealous of your fame than myself, and none desires so sincerely that you should by your conduct in the expedition furnish to your friends and your country an excuse for undertaking it." Not long after, Magee succumbed to his ailment and Colonel Samuel Kemper assumed command of the "Mexican Revolutionary Army." ${ }_{42}$

Shaler's anxiety for the army's condition at La Bahía during December was soon relieved when he received a letter from Reuben Ross of Virginia who held the rank of major in the invading force. Ross recounted the details of several successful skirmishes with royalist troops who were attempting to encircle La Bahía. Remarking on their condition in the event of a siege, Ross listed a six-month supply of corn and "one hundred thousand" in their treasury. It would appear the army suffered little from a lack of monetary aid, but nothing is yet certain as to the source of these extensive funds. Finally, Ross observed that he would soon return to Natchitoches to lead back "several tribes of Indians to the number of about two hundred warriors, who had volunteered their services. . . ." Ross apparently spent much of winter attempting to organize members of various tribes. During February, 1813, Shaler reported to Monroe that 500 members of Pawanese (Pawnee?), Trois, Cannes, and other subtribes had assembled on the

41 NA, Shaler to Monroe, 29 November 1812 with enclosure, Magee to Shaler, undated; Gutiérrez to Shaler, 25 November in Spanish; 29 November in Spanish.

${ }^{2}$ NA, Shaler to Monroe, 27 December 1812 with enclosures, Magee to Shaler, 25 November; Shaler to Magee 20 December. 
banks of the Brazos River while 200 Alabamas, Conchatties, and Choctaws were awaiting Ross on the Trinity River. A problem arose with the latter Indians, however, since their "Caddo" refused to join the insurgent army unless they flew the flag of the United States. ${ }^{43}$

While Ross sought reinforcements, the revolutionary army broke through the royalist ring and, turning upon the Spanish troops under the command of the Governor General of Texas, Manuel de Salcedo, inflicted a severe defeat. Gutiérrez wrote Ross and Shaler the news that in the engagement on 10 February 1813,150 royalists were killed, eleven wounded, and fifty-one prisoners were taken. Bernardo gleefully reported the Spanish flight to San Antonio to be in complete disarray and that many rebels only awaited a supply of arms and his own arrival..4 This news apparently reached Shaler sometime before the beginning of March and it prompted him to request a passport from the State Department in anticipation of following the army. The passport was duly approved and forwarded to him. Acknowledging its arrival, Shaler commented that "nothing now, Sir, prevents me from proceeding on my journey but the fear of being regarded as a partizan in the revolution, and thereby (openly?) committing the government." ${ }^{45}$

Concurrent with these events Shaler announced to Monroe that on 4 April there arrived in Natchitoches another revolutionary agent " destined to command the Mexican armies in Texas." José Álvarez de Toledo had represented Santo Domingo at the Cortes of Cádiz, but after being censured by that body he travelled to Philadelphia and there espoused the Republican cause by writing letters to the editor of that city's Gazette and delivering lectures on Mexican independence. Bernardo met him in Washington and had been favorably impressed. "Today," Gutiérrez penned in his diary, "I have been rejoicing because Señor Álvarez de Toledo has come from Philadelphia; he is a man of great talents, and passionately devoted to the cause of the liberty of Mexico. . . ." According to a contemporary account, the two men conspired at this meeting to invade the eastern province of New Spain. The accuracy of this account is uncertain, but in spite of any friendship

${ }^{43}$ NA, Shaler to Monroe, 10 January 1813 with enclosure, Ross to Shaler, undated. Wellman claims the invasion force had little organization and no commissary. Wellman, op. cit., p. 209; Shaler to Monroe, 8 February.

44 Ibid., Shaler to Monroe, 24 February with enclosure, Gutiérrez to Ross, undated. Nichols stated simply that the Spanish gave up on the siege of La Bahía and retreated. Nichols, op. cit., p. 93.

${ }_{45}$ NA, Shaler to Monroe, 3 April 1813. Nichols makes no mention of a passport request or approval. 
they had, the two were soon to become mortal enemies. On 11 April 1813 Bernardo wrote to a friend that Toledo was bent on treachery and had shown himself to be an advocate of the royalist cause. ${ }^{48}$

While this feud was ominously developing, rebel activity accelerated with the onset of spring. On 13 March, Major Ross joined Bernardo and Kemper on the road to San Antonio with reinforcements composed of 100 North Americans, some of whom were Indians. Captain Richard MacFarlene moved in their direction with 300 Indian volunteers and Shaler confided to Monroe that the insurgent army, without the preceding numbers, had the strength of 800 effectives (not counting foragers, mule skinners, other support elements or those on the sick list). As this force neared the Texas capital, Salcedo sallied forth to check its advance in front of 3,000 troops and twenty-nine pieces of artillery. When the two forces came within musket range at Rosillo on 29 March, Salcedo attacked with a deafening artillery bombardment. The royalist guns, however, fired only one salvo before the Tennessee and Kentucky sharpshooters cut down the Spanish gunners. ${ }^{47}$

In his official report of the action, Shaler portrayed a signal victory for the revolutionary forces. The royalist army "was completely routed in half an hour with great slaughter and the loss of all his cannon." While commenting on the gallantry and bravery exhibited by several North Americans during single combat with Spanish officers, Shaler also noted that five of his countrymen were killed, as well as two Mexicans and two Indians. With the cannon was seized 4,000 pounds of powder, and the insurgents, Shaler jubilantly chortled, were in "undisputed possession of the province." Salcedo's force was all that had opposed the route to the Rio Grande and nearly 1,000 had been killed or wounded. Of the total royalist force, less than 300 managed to reach San Antonio and many of these hastily departed from there to their homes. In two days the insurgents reached the Capital and on the first of April, the city capitulated without a struggle. ${ }^{48}$

Unfortunately, the ensuing events marked the beginning of the revolutionary army's decline and to a great degree caused the United States Government to revise drastically its policies concerning Mexico.

46 lbid., Shaler to Monroe, 4 April 1813; Shaler to Monroe, 18 April with enclosure, Gutiérrez to Cogswell, 11 April; Gutiérrez Diary, op. cit., p. 75; Niles, op. cit., p. 148. Shaler took it upon himself to send Toledo a copy of Bernardo's letter in which the latter called him a traitor. This action apparently alienated Toledo and caused the rift between the two to widen.

${ }^{47}$ NA, Shaler to Monroe, 3 April and 12 June; Wellman, op. cit., p. 210.

48 NA, Shaler to Monroe, 7 May 1813; Bancroft, op. cit., p. 23; Wellman, op. cit., p. 210. 


\section{IV}

... So insignificant and contemptible a character as Jose Bernardo Gutierrez ... are precisely the poisonous vipers we should combat and destroy, ... who under the mask of hypocrisy invoke in public the Virgen of Guadaloupe, and making the sign of the cross conspire against the dignity and glory of the Mexican people.

-Shaler and Toledo editorial; El Mexicano, 19 June 1813

Even before Shaler heard of the startling victory at San Antonio, a drama was unfolding in a desolate arroyo a few miles from the newly captured city which was to alter greatly the future of the insurgents in Mexico.

When Salcedo surrendered San Antonio to the rebels, he did so to avoid further bloodshed. He cheerfully congratulated the North American officers on their success and jested that he preferred this meeting to one on the field of battle. His deputy, Simon de Herrera, was also "cheerful and did not appear to regard the occurrence as a misfortune." That evening the Spanish and North American officers shared dinner while "Bernardo penned himself up with the Army in the stone enclosures of the Mission de los Alamos one and a half miles distant." The next morning, 2 April, Bernardo ordered the Spanish officers, including Salcedo, Herrera, and twelve others, escorted to La Bahía by Criollo troopers. They returned the following day, casually reporting to all and sundry "that they had butchered them all by order of the General (Bernardo)" a short distance from the city. Horrified by the brutality, the North American officers were again shocked to observe a celebration by the Criollo inhabitants of San Antonio upon their reception of the news. In an attempt to justify his action and to continue receiving Shaler's support, Bernardo explained to the latter that similar inhumanities had been committed by Salcedo upon the citizens of Texas and they had demanded retribution. He asserted, moreover, that the people had disposed of the Spanish officers, not he. ${ }^{49}$

Neither accepting Bernardo's explanation nor comprehending Criollo mentality, Shaler became determined to unseat Gutiérrez and expose him as a barbaric despot. On 7 May, the day word of the massacre was received, Shaler informed Monroe that he would proceeed immediately to San Antonio as "it appears to me important to the U. S. as well as to humanity." The special agent suggested that Toledo be

${ }^{40}$ NA, Shaler to Monroe, 7 May 1813; Shaler to Monroe, 14 May with enclosures, Gutiérrez to Shaler, 11 April; Shaler to Monroe, 12 June. 
placed in command of the rebel army since the massacre had cast a shadow on the United States' unofficial support of the rebellion and because Bernardo was living "in the Style of an Eastern Basha. . . ." Finally, Shaler considered the Colonel's promulgation of a constitution, to which Shaler himself had contributed, "nothing more than an absurd revolutionary farce." so

Before he departed for Mexico, Shaler forwarded copies of the constitution and several proclamations that had been delivered to the populace of Texas. Shaler further reported that Gutiérrez had appointed a junta empowered with all the trappings of government which was responsible to no one but him and "that junta proclaimed him Governor of the province. ..." One proclamation praised the actions of the North American volunteers and encouraged the "emigration of freemen from all Nations who are desirous of uniting with us in the protection and enjoyment which a republican government can guarantee to man." Bernardo also wrote Shaler requesting him to forward the gratitude of Mexico for its freedom to Washington and pompously noted, "It would please me much to see Americans removing from the Louisiana, Missouri, and other remote parts of your country less improved than this part of Nueva España, to settle either on the frontier or the interior parts of this province." ${ }^{51}$

On 19-20 May, Shaler departed for Nacogdoches with the intention of proceeding to San Antonio but, apparently uncertain of whether his government would approve, returned to Natchitoches. He observed that Bernardo seemed to have considered his labors as terminated and was currently enjoying the fruits of his conquest. Vehemently criticizing the provisional government, Shaler exclaimed that not one in ten knew anything concerning administrative procedure. "In the formation of his junta," Shaler claimed, "the most ignorant and least respectable characters in the country " were chosen for the positions. ${ }^{52}$

Their disreputability became evident a few days after their installation when one of the members was convicted and imprisoned for theft. Moreover, the junta had yet to pass on a single useful provision and no allocations had been made for the army since San Antonio's capture which left that body "destitute of everything. . .." Consequently,

50 $\mathrm{Ibid}$., Shaler to Monroe, 14 May with enclosures; Gutiérrez to Shaler 18 April. Wellman contends that the North Americans immediately deserted Gutiérrez after the massacre. Wellman, op. cit., p. 211.

${ }_{51}$ NA, Shaler to Monroe, 14 May 1813 with enclosure; Gutiérrez to Shaler, 11 April. 52 lbid., Shaler to Monroe, 12 June. 
1,200 rebels had deserted and more were daily disappearing. The government, however, was apparently very active in one area of administration. Shaler noted that arbitrary imprisonments and confiscations "constantly succeed each other" to such an extent that all the resources of the surrounding country "have been pillaged, and squandered away without any public benefits." 53

As with most unexpected conquests in an area legendarily wealthy, men became drawn to the new republic regardless of a deteriorating situation and most of their aid was unsolicited. Shaler learned that 600 Frenchmen from New Orleans were organized into two regiments and ready to be unleashed on Texas under the command of a Colonel Rozelli (Rossilli?) from Santo Domingo. Their plan was so well advanced that they had sent a small vanguard to the port of Matagordo to secure a landing site for their boats. Shaler suspected they were thieves and cutthroats from Barataria and assumed them to be actually led by that famous pirate Jean Lafitte or his brother André. Fearing the worst for Texas, Shaler concluded that " such a body of men to take possession of and fortify themselves in it would immediately become an asylum for all the foreign adventurers in the U. S. who would probably so strengthen themselves in a short space of time as to render their expulsion ... a doubtful enterprise." ${ }_{54}$

To further confuse the situation, royalist activity reasserted itself in the form of an army of 1,500 men which assembled some few miles above the Rio Grande under the guidance of the Spanish Colonel Arredondo. Then, too, the smoldering feud between Gutiérrez and Toledo erupted and Shaler was hard put to defend his new found Mexican liberator. Subsequent to several negotiations and a dramatic confrontation between Bernardo's authorized representative, Shaler and Toledo, the latter was cleared of any treacherous activity with the Spanish. ${ }^{55}$ The onerous charges leveled at Toledo during the dispute only strengthened Shaler's determination to crush Gutiérrez and replace him with Toledo. Since the latter had been assigned to garrison Nacogdoches, he and Shaler were near and able to mount a propaganda offensive against the self-appointed Texas Governor.

Their first alliance produced a broadside newspaper entitled Gaceta de Texas, but it appeared for only one issue. Their next attempt culmi-

\footnotetext{
53 Ibid.

${ }^{54}$ Ibid., Shaler to Monroe, 19 September 1813.

$55 \mathrm{Ibid}$., Shaler to Monroe, $11 \mathrm{April}$; Shaler to Monroe, 12 June with enclosure, Shaler to Gutiérrez, undated; Shaler to Monroe, 10 July. Nichols' account omits any rendition of the Gutierrez-Toledo feud.
} 
nated in the publication of El Mexicano which headlined the motto: "La Salud del pueblo es la Suprema Ley." In a feature editorial Shaler and Toledo directly accused Gutiérrez by name of the "most frightful calamities." Whether this attack was successful is uncertain, but by June most of the North Americans and a large segment of San Antonio had had their fill of Bernardo and were seeking an excuse for his removal. Caution was exercised, however, since the revolutionary leader was something of a hero to many of his fellow Criollos. When on 14 June a false alarm was sounded, Bernardo's actions presented the North Americans with an opportunity to replace him. A very distraught Gutiérrez immediately ordered an abandonment of the city and a retreat to distant Trinidad. He again implored Majors Ross and Kemper to offer Texas to the United States if troops were promptly dispatched to defend it. Since no preparations had been made to repel an attack, supposed or real, Ross resigned in disgust and immediately departed for the northern border taking not a few of his countrymen with him. ${ }^{56}$

A few days hence another alarm was given and this time proved accurate. Under a flag of truce a royalist envoy proposed that the city surrender, promising safe conduct to the border for the North Americans upon their deliverance of Gutiérrez and sixty others. A brash young officer from Connecticut, Major Henry Perry by name, proposed a bold attack on the enemy's superior forces which was to be spearheaded by the remaining 500 North Americans and 200 Indians. That they were victorious was astounding for they faced a fully equipped and experienced regular force of 1,000 royalists. While sustaining only thirty casualties, the North Americans managed to kill or wound 300 and take seventy-eight prisoners while the remainder of the Spanish army scattered. Bernardo took no part in any decision during the action and the North Americans took advantage of this to urge Shaler to bring Toledo with him to San Antonio as soon as it was possible. $^{57}$

Hearing no word from Monroe for some time regarding his repeated remarks of journeying to San Antonio, Shaler sent Toledo alone on 3 July. A few days earlier, the junta met with the North American and Criollo officers and voted unanimously to accept Toledo. Gutiérrez gracefully absented himself from the session and announced his intention to retire across the border. Conscientiously delayiing his own departure, Shaler once again informed Monroe of his intention to travel

${ }^{56} \mathrm{Ibid}$., Shaler to Monroe, 20 June 1813 with enclosures; Shaler to Monroe, 10 July. ${ }^{57}$ lbid. 
to the aid of his countrymen and the revolution on twenty-four hours notice. He also alerted his superior to Toledo's plan to annul Bernardo's "absurd government," to form a junta by the free suffrage of the people, and to march immediately southward. Unable to resist an additional plea, Shaler closed his report with a dramatic portrayal of the revolution teetering on the brink of disaster. The United States, he implied, had one final opportunity to force a successful rebellion and Shaler was firmly committed to that attempt: "I have therefore determined to proceed and support Toledo in every way in my power consistent with my situation; this from the unbounded confidence all parties have in me will be an easy task." ${ }^{58}$

In his zeal to aid the revolution Shaler failed to realize the precarious situation of the insurgents. Royalist troops had been converging on San Antonio for several weeks and the rebel army was all but surrounded. Based on intelligence from Shaler's voluminous correspondence and not emotionally involved, Monroe was apparently able to conclude that the revolution was doomed. The massacre and subsequent dispute over leadership amongst the rebels had precluded any direct United States aid and compelled the pragmatic Secretary of State to abandon any continuance of clandestine support. Probably for the first time Monroe considered Shaler's actions as indiscreet and on 5 June he ordered the special agent to remain in Natchitoches, severing his relations with the insurgents. Monroe, moreover, had more than he was able to cope with in Washington. The war with the British was developing contrary to expectations and each week brought news of reverses suffered by United States arms. The Secretary's command, written in haste and sandwiched between urgent dispatches from the Canadian border, did not reach Shaler until 7 August while he was on the San Antonio road. Obediently returning across the border, Shaler penned to Monroe his regrets if his intentions had offended the President, and in succeeding paragraphs he outlined all the previous precautions that had been observed in order that the United States would not be directly implicated in the invasion and subsequent revolution. ${ }^{59}$

During the latter part of August 1813, the final blow descended as Monroe foresaw, and the revolution shattered from its impact. From

58 Ibid., Shaler to Monroe, 14 July 1813.

59 Nichols, op. cit., p. 95. NA Shaler to Monroe, 7 August 1813. The summer of 1813 was a period of disastrous news for the United States. Beginning with the failure of the invasion of Upper Canada the latter part of 1812, the gloom that hung over the country darkened when it was learned that the U.S.S. Chesapeake had been captured in June, 1813. On 6 June a force of 2,000 Americans was defeated at Stony Brook by only 700 British troops. J. M. Hitsman, The Incredible War of 1812 (Toronto: University of Toronto Press, 1965), pp. 71-75; 134-135; 142. 
an invasion force that had numbered more than 2,000 effectives at its peak, 300 managed to escape across the border; the Mexicans in that number bringing their families to escape reprisal. From interviews with the survivors, Shaler managed to piece together the fate of the missing North Americans and the rebellion's final moments. He learned that nearly 600 ex-rebels, many of them his countrymen, had avoided capture but were scattered throughout the border provinces. Fifty North Americans were captured at Trinidad by a detachment of Spanish cavalry under the command of a Colonel Elisondo, but were furnished with pack horses and passports to return home. These captives informed Shaler that Elisondo had given them liberty to remain in Texas if they would swear to refrain from revolutionary activities. If, however, the United States chose to invade Mexico in the future, Elisondo promised its forces "would find no enemies."

Other insurgents were not so fortunate. Every Spanish soldier who had deserted to the revolution (possibly 200 men) was promptly shot upon capture. An unknown number of North Americans also shared a similar fate and Bancroft has estimated that of 850 North Americans present at the final struggle, only ninety-nine escaped to Natchitoches. ${ }^{{ }^{11}}$

José Álvarez de Toledo was one of the fortunate to attain safety and with his arrival in Natchitoches on 7 September, the Texas Revolution officially ceased to exist for all parties concerned. There remained nothing more for Shaler to accomplish on a suddenly deserted frontier but submit bills for his expenses related to Bernardo and Toledo. Excluding his lodgings, Bernardo's costs totaled $\$ 596.90$, while Toledo's brief career amounted to $\$ 415$, half of which went for a horse and saddle. $^{.2}$

\section{V \\ As the inhabitants of South America aspire by all possible means to patronize ... interests with the North Ameri- cans, I cannot believe that the latter will remain cool spec- tators of the great struggle sustained by the former against European Tyranny. \\ -Toledo to Shaler, 28 November 1813}

\footnotetext{
60 NA, Shaler to Monroe, 19 September 1813; Shaler to Monroe, 28 November with enclosure, Overton to Shaler (in Spanish), 17 November. Elisondo had earlier earned a reputation as the betrayer of Morelos (Wellman, op. cit., p. 210). A North American survivor, Captain Overton, informed Shaler that shortly after Elisondo released him and his men, he was killed by one of his own officers because he refused to execute the North Americans.

${ }^{61}$ Bancroft, op. cit., p. 27; Wellman, op. cit., p. 210; NA, Shaler to Monroe, 19 September.

62 Ibid., Shaler to Monroe, 4 October 1813.
} 
Never to have contact with each other again, the revolutionaries pursued their own ways and the Spanish province of Nueva España remained, partly as a result of their catastrophe, passive to independence movements for another five years. Defeated in repeated machinations and clandestine invasion plots, Toledo finally submitted to the King's mercy and spent his remaining years as the Spanish Ambassador to the Court of Naples. ${ }^{63}$ Gutiérrez remained in Natchitoches until 1821, but was active in other attempts to invade his homeland. He nearly succeeded in recruiting Andrew Jackson's demobilized veterans of the Battle of New Orleans, but the plan was squelched when President Madison intervened. Issuing a proclamation on the first of September 1815, the President warned those involved in invasion schemes to cease their "unlawful enterprizes . . . as they will answer the contrary at their peril." After Mexico's independence, Bernardo settled in Tamaulipas and subsequently became the governor of that state. ${ }^{64}$ William Shaler never returned to Mexico after his departure from Natchitoches during the fall of 1813. Reassigned to Ghent and later Algiers, his later life was marked by subdued qualities he had not revealed on the Mexican border. ${ }^{65}$

The impact of the invasion, however, did not fade as rapidly as the participants. On the final day of 1815 , Nueva España's viceroy, Don Félix Calleja, wrote his government's Minister of War that " the government of Washington, which is interested in the emancipation of these provinces, and is desirous of forming a government for them after the model of its own," should be discouraged by the dispatching of "cruisers to the coast of Vera Cruz, and likewise land as well as naval forces. ..." Fearing the worst, Calleja stated it would be necessary to be prepared "in case the factions in North America should realize their meditated invasion." Earlier, the Spanish Government published an indulto which placed a price on the heads of Toledo, Gutiérrez, and two others who were North Americans. The decree stipulated that the reward would only be paid if proof of their deaths could be furnished. ${ }^{86}$

Deeply committed to a war with Britain that was proving to be a disaster, the United States was forced to abandon its earlier Mexican

${ }^{63}$ Bancroft, op. cit., p. 31; NA, Toledo to Shaler, 28 November 1813 with enclosures; Toledo to Shaler, 8 November.

${ }^{64}$ M'Caleb, op. cit., p. 225. This writer claims Gutiérrez was not aided by the United States; Richardson, op. cit., p. 547; Gutiérrez Diary, op. cit., pp. 60-61; Anon., Outline of the Revolution in Spanish America by a Soutb-American (London: Longman, etc., 1817), p. 345.

${ }^{85}$ NA, Diplomatic Instructions, All Countries, 393 and 406.

${ }_{66}$ Bancroft, op. cit., p. 33; Outline, op. cit., pp. 336-7. 
policies of aid and penetration. By 1817 Congress overwhelmingly passed an act designed to preserve United States neutrality towards all Latin American wars of Independence. Under its provisions, the President was specifically authorized to forbid the sale of warships by United States citizens to subjects of any power and the exportation of arms to anywhere in the Western Hemisphere was strictly prohibited. It would appear that one of the great losses incurred during the War of 1812 was the Latin American policy of the United States. ${ }^{87}$

A few additional points require mentioning. While this work presents only a portion of the contacts between the United States and Mexican revolutionaries during those turbulent years, it is clear that further study is mandatory before a definitive reappraisal of the relations between these neighboring states in the first decades of the nineteenth century is possible. The aforementioned account of William Shaler's activities and the discrepancies found in earlier studies would seem to demand it. Shaler would certainly not have acted as he did if he had been aware that such conduct would not have met with Monroe's approval. In fact, Shaler's furious attempt to have Gutiérrez replaced by a Monroe-supported Toledo, when the former strayed from the revolutionary path, points to the credibility of the argument that the expedition was not a filibuster but a United States sponsored scheme to aid the Mexican Revolution. ${ }^{68}$

Finally, a note regarding United States relations with the Mexican Republic will serve to bulwark this work's thesis. After independence, the fear of a North American invasion was transferred from Madrid to Mexico City. Never forgetting the ulterior motives behind the invasion of 1812-13 and subsequent private incursions, the first Mexican representative accredited to Washington wrote his superiors in 1822:

The arrogance of these republicans does not permit them to see us as equals but as inferiors; their conceit extends . . . to the belief that their capital is that of all the Americas; they have an intimate inferest in our money, not to theirs, neither are they disposed to enter into a treaty of alliance or commerce. ... With the passage of time they will be our sworn enemies ... and there is no doubt that the object of their ambitious plans is the province of Texas. ${ }^{69}$

Richard W. Gronet

Catholic University,

Washington, D.C.

${ }^{67}$ Niles, op. cit., p. 187; Whitaker, op. cit., p. 95.

${ }^{68}$ Cox, op. cit., p. 215. While not mentioning Shaler by name, Cox suggests that Monroe's subordinates probably would not have aided the revolution if they knew Washington would have disapproved.

${ }^{69}$ Federico Gamboa, ed., La Diplomacia Mexicana (Mexico: Tipografia 'Artistica,' 1910), p. 103. 